\title{
PENGEMBANGAN BAHAN AJAR BERBASIS PENELITIAN KARAKTERISASI PROTEIN MEMBRAN SPERMA PADA MATAKULIAH BIOTEKNOLOGI
}

\author{
Ika Oktaviana ${ }^{1)}$, Sutiman B Sumitro ${ }^{2)}$, Umie Lestari ${ }^{3)}$ \\ Program Studi Pendidikan Biologi Pascasarjana Universitas Negeri Malang \\ Email: Ikaoktaviana71@ gmail.com.
}

Diterima 8 Agustus 2015 disetujui 20 Oktober 2015

\begin{abstract}
The purpose of the research and development is to produce teaching materials such as textbooks supporting course in Biotechnology research based on the characterization of the sperm membrane proteins for students who take a course in Biotechnology. This research is a research and development, where the results of research become the teaching materials developed supporting Biotechnology course. Development models have prepared using ADDIE Model. Sources of data in this research include laboratory research and validation of the results sheet of Biotechnology material experts, instructional design experts, the media, and the trials in students. The analysis is used descriptive analysis and quantitative descriptive exploratory. The results of the research have developed become teaching materials like text books supporting courses and have been validated by the Biotechnology, the biotechnology material experts, instructional design experts, the media, the individual testing, and group trials. Based on the results of the validation material have obtained value of $89.56 \%$, the results of the design validation and media experts to get the value of $93.75 \%$, it means that the teaching materials has been developed which suitable to be used as a teaching material support biotechnology course. While the experiments performed to get a data the percentage of students that are equal to $88.98 \%$ and included in the category of "very good", but still need to be revised based on advices and comments from students.
\end{abstract}

Keywords: Teaching material, Characterization of Membrane Proteins, Biotechnology.

\section{PENDAHULUAN}

Bioteknologi adalah ilmu biologi molekuler berikut teknik dan aplikasinya yang digunakan untuk memodifikasi, memanipulasi atau merubah proses kehidupan normal dari organismeorganisme dan jaringan-jaringan guna meningkatkan kinerjanya bagi keperluan manusia. Bioteknologi merupakan bidang yang yang dianggap sulit, tetapi sekaligus juga merupakan bidang yang sangat berkaitan dengan peningkatan kesejahteraan manusia, sehingga tetap dibutuhkan penguasaan di bidang ini (Primose, 2003). Bioteknologi memiliki beberapa karakteristik diantaranya merupakan ilmu yang bersifat multidisipliner,lebih banyak bersifat aplikatif sehingga membutuhkan penguasaan konsep-konsep dasar yang benar, banyak menimbulkan kontroversi (terutama produk-produk bioteknologi yang bersifat transgenik) dan berkembang sangat pesat karena manfaatnya bersentuhan langsung dengan peningkatan taraf hidup manusia (Roitt, 2000).

Bioteknologi didalam pembelajaran merupakan matakuliah wajib yang harus ditempuh oleh mahasiswa jurusan Biologi FMIPA Universitas Negeri Malang. Dalam pelaksanaan pembelajarannya digunakan suatu kompetensi berupa suatu Rencana Pembelajaran Semester (RPS) yang memuat tentang standart kompetensi tentang pemahaman hakikat dan prinsipprinsip Bioteknologi sebagai ilmu pengetahuan dan pengembangan teknologi dalam rangka untuk meningkatkan kesejahteraan manusia.

Matakuliah Bioteknologi lebih ditekankan pada teknik-teknik/langkah-langkah dalam pembuatan produk bioteknologi sehingga bahan ajar berbasis penelitian pada matakuliah bioteknologi sangat dibutuhkan 
dalam perkuliahan, akan tetapi kurangnya bahan ajar berbasis penelitian yang dikembangkan oleh mahasiswa Indonesia yang melakukan penelitian/melakukan teknik-teknik yang mengacu pada bioteknologi maka diperlukan pengembangan bahan ajar berbasis penelitian untuk matakuliah bioteknologi.

Bioteknologi mempunyai peranan yang sangat penting dalam peningkatan kesejahteraan hidup manusia. Namun dalam penerapannya perlu memperhatikan aspek sains dan teknologi, serta memperhatikan aspek masyarakat dan lingkungan.oleh sebab itu, materi bioteknologi ini dapat diajarkan dengan pendekatan sains, lingkungan, teknologi dan masyarakat (SETS).

Pendekatan sains, lingkungan, teknologi dan masyarakat (SETS) merupakan bentuk kegiatan pembelajaran yang mengaitkan secara timbale balik unsure-unsur sains, lingkungan, teknologi dan masyarakat (Binadja, 2005). Tujuan dari pendekatan ini adalah untuk membentuk individu yang memiliki literasi sains dan teknologi serta memiliki kepedulian terhadap masalah msyarakat dan lingkungannya. Seseorang yang memiliki literasi sains dan teknologi ialah seseorang yang memiliki kemampuan menyelesaikan masalah menggunakan konsep-konsep sains yang diperoleh dalampendidikan sesuai jenjangnya, mengenal produk bioteknologi yang ada disekitarnya beserta dampaknya, mampu menggunakan produk bioteknologi dan memeliharanya, kreatif membuat hasil teknologi yang disederhanakan dan mampu mengambil keputusan berdasarkan nilai.

Bahan ajar yang dikembangkan juga harus mengacu pada salah satu kompetensi dasar yaitu menjelaskan prinsip-prinsip bioteknologi yang menghasilkan produk antibodi. Sedangkan indikator kompetensi yang harus dicapai mahasiswa bioteknologi adalah mampu memahami prinsip dasar antibodi, mahasiswa mampu memahami teknik-teknik antibodi poliklonal protein membran, mahasiswa mampu memahami karakterisasi protein membran sperma, serta mahasiswa mampu memahami teknikteknik dalam analisis antibodi protein membran antara lain teknik isolasi protein, elektroforesis, imunisasi, uji antibodi hasil imunisasi melalui ELISA.

Berdasarkan latar belakang yang telah disampaikan maka peneliti ingin mengembangkan bahan ajar berupa buku teks matakuliah Bioteknologi yang memuat tentang teknik karakterisasi protein membran sperma. Pengembangan bahan ajar digunakan peneliti untuk mendesain dan mengembangkan pembelajaran efektif dan efisien. Model pengembangan yang digunakan adalah ADDIE ini didasarkan atas pemikiran bahwa model ini: 1) memberikan kesempatan untuk melakukan revisi (evaluasi) secara terus menerus dalam setiap tahap yang dilalui sehingga dapat menghasilkan suatu bahan ajar yang lebih baik, 2) model ini sangat sederhana namun implementasinya sistematik, 3) model ini dikembangkan secara sistematis dan berpijak pada landasan teoritis desain pembelajaran. Model ini terdiri atas lima langkah, yaitu: (1) analyze (analisis), (2) design (perancangan), (3) development (pengembangan), (4) implementation (implementasi), dan (5) evaluation (evaluasi) (Branch, 2009).

\section{METODE}

Prosedur penelitian pengembangan bahan ajar berupa buku teks penunjang matakuliah Bioteknologi dilakukan dengan mengacu pada model pengembangan ADDIE. Model ini disusun secara terprogram dengan urutan-urutan kegiatan yang sistematis dalam upaya pemecahan masalah belajar yang berkaitan dengan sumber belajar yang sesuai dengan kebutuhan dan karakteristik pebelajar. Model ini terdiri atas lima langkah, yaitu:
(1)
analyze (analisis),
(2) design 
(perancangan), (pengembangan),

development

(implementation), dan implementasi (evaluasi).

\section{Analyze/Analisis}

Tahap analisis dilakuakan dengan mengidentifikasi dan mengembangkan pemahaman yang jelas tentang kebutuhan peserta didik mengenai bahan ajar Bioteknologi. Hal ini disebut dengan tahap analisis kebutuhan, terdapat dua tahapan dalam analisis ini yaitu: a) analisisi kurikulum dan b) analisis sumber belajar. Analisis kurikulum dilakukan untuk mengetahui dan mengklarifikasi silabus yang dikembangan oleh kelompok bidang kajian mata kuliah Bioteknologi Jurusan Biologi Universitas Negeri Malang. Berikut merupakan hasil analisis kurikulum yang telah dilakukan.

a. Standar Kompetensi:

Memahami hakikat dan prinsipprinsip Bioteknologi sebagai ilmu pengetahuan dan pengembangan teknologi dalam rangka untuk meningkatkan kesejahteraan manusia.

b. Kompetensi Dasar:

Menjelaskan prinsip-prinsip bioteknologi yang menghasilkan antibodi.

c. Indikator Kompetensi:

1. Mahasiswa mampu memahami prinsip dasar antibodi

2. Mahasiswa mampu memahami karakterisasi protein membrane sperma

3. Mahasiswa mampu memahami teknik isolasi, teknik elektrofesis, teknik imunisasi, dan uji ELISA

Sedangkan analisis sumber belajar bertujuan untuk mengetahui kebutuhan bahan ajar Bioteknologi yang sesuai dengan karakteristik mahasiswa pada program studi Biologi Universitas Negeri Malang. Tujuan dari analisis kebutuhan penelitian ini adalah untuk: a) mengidentifikasi bahan ajar Bioteknologi yang sudah ada, b) mengidentifikasi kelemahan bahan ajar yang sudah ada, c) mengidentifikasi permasalahan yang dihadapi mahasiswa dalam memahami materi Bioteknologi dan c) menentukan materi Bioteknologi yang akan dijadikan sebagai bahan ajar Bioteknologi.

\section{Design/Desain}

Tahap perancangan (design) dilakukan perencanaan bahan ajar berupa buku teks tentang karakterisasi protein membran sperma. Selain itu, pada tahap ini juga dilakukan perancangan bahan ajar dimana pengembangan buku teks ini didasarkan dari hasil tentang karakterisasi protein membran sperma di laboratorium.

a) Rancangan Penelitian Karakterisasi Protein Membran Sperma

1) Alat

Alat yang digunakan dalam penelitian ini antara lain centrifuge refrigerated, machine centrifuge, tabung sentrifuse, neraca analitik, pH meter, mortar, Autoclave, Biorad elektrophoresis, ELISA reader, micropipet, tip-micropipet.

2) Bahan

Bahan yang digunakan dalam penelitian ini antara lain fenil metal sulfonil flourida (PMSF), phospat buffer saline (PBS), asam klorida (HCl), Tri-Cl, Tris-base, Tween 20, Poliakrilamid, Bis-acrylamid, Comassie-blue R-250, Protein marker, Freund adjuvant, Mice IgG-AP konjugat, enzyme substrat TMB, RSB, Tris $\mathrm{pH} \mathrm{8,8,} \mathrm{Tris} \mathrm{pH}$ 6,8, aquadest steril, Deionize water, TEMED, APS, SDS, larutan staining,larutan destaining, running buffer.

3) Prosedur Kerja 
a) Isolasi protein membran sperma manusia

b) Pengukuran Kadar Protein membran sperma manusia dengan Metode Nano Drop

c) Penentuan berat molekul isolat protein membran sperma dengan menggunakan Elektroforesis SDS-PAGE

d) Persiapan Hewan coba dan imunisasi protein $116 \mathrm{kDa}$

e) Produksi Dan Purifikasi serum darah yang mengandung Antibodi Protein $116 \mathrm{kDa}$

f) Uji ELISA

\section{Rancangan Bahan Ajar Berbasis Penelitian}

Desain bahan ajar karakterisasi protein membran sperma akan disusun berdasarkan hasil penelitian dengan rancangan pada Tabel 1.

Tabel 1 Rancangan Bahan Ajar

\begin{tabular}{l}
\hline Judul Buku Karakterisasi Protein Membran Sperma \\
\hline Kata Pengantar \\
Daftar Isi \\
Daftar Gambar \\
Daftar Tabel \\
Daftar Singkatan \\
Bab I Pendahuluan \\
Bab II Protein Membran Sel \\
Bab III Teknik Analisis Protein \\
Bab IV Teknik Analisis Protein Membran Sperma \\
Bab V Sistem Imun \\
Bab VI Produksi Antibodi \\
Daftar Pustaka \\
\hline
\end{tabular}

\section{Development/Pengembangan}

Tahap ketiga adalah kegiatan pengembangan (development) yang meliputi kegiatan penyusunan buku teks penunjang matakuliah Bioteknologi. Kegiatan pengumpulan bahan/materi buku teks, pembuatan gambar-gambar ilustrasi, pengetikan, dan sebagainya merupakan kegiatan pada tahap pengembangan ini.

Pada tahap pengembangan ini mengumpulkan dan menyusun materi yang disajikan dalam buku teks. Materi disusun dengan bahasa yang sederhana agar mahasiswa mudah memahami materi yang disajikan. Selanjutnya pengetikan teknikteknik yang dilakukan dalam penelitian dan juga menyusun gambar-gambar dokumentasi hasil penelitian.

Setelah tahap pengembangan buku, kemudian dilanjutkan pada uji coba bahan ajar Bioteknologi oleh para ahli yang melibatkan satu orang ahli materi Bioteknologi, satu orang ahli media dan design pembelajaran. Kemudian dilakukan evaluasi formatif hasil validasi berupa revisi dari ahli isi materi Bioteknologi, dan dilanjutkan dengan evaluasi formatif hasil validasi berupa revisi dari ahli dan desain pembelajaran.

Setelah mendapat validasi atau dinyatakan layak sebagai bahan ajar Bioteknologi, maka dilakukan uji coba kelompok perorangan oleh 3 orang mahasiswa. Hasil uji coba perorangan digunakan untuk mengevaluasi bahan ajar penunjang matakuliah Bioteknologi dari segi keterbacaan. Selanjutnya dilakukan uji coba kelompok sedang kepada mahasiswa Bioteknologi yang sedang mengikuti matakuliah Bioteknologi dengan menggunakan angket sebagai pengumpulan data. Hasil uji coba klasikal digunakan dalam mengevaluasi bahan ajar penunjang matakuliah Bioteknologi untuk melihat tingkat efisiensi dari buku teks Bioteknologi yang dikembangkan. Tanggapan serta masukan dari uji coba perorangan dan uji coba kelompok kecil digunakan untuk revisi tahap selanjutnya. Kisi-kisi komponen yang akan divalidasi dapat dilihat pada Tabel 2 dan Tabel 3. Angket berisi kolom-kolom yang menunjukkan tingkatan jawaban. Kriteria penilaian bahan ajar dapat dilihat pada Tabel 4. 
Tabel 2 Kisi-kisi Instrumen Lembar Validasi Ahli Materi Bioteknologi

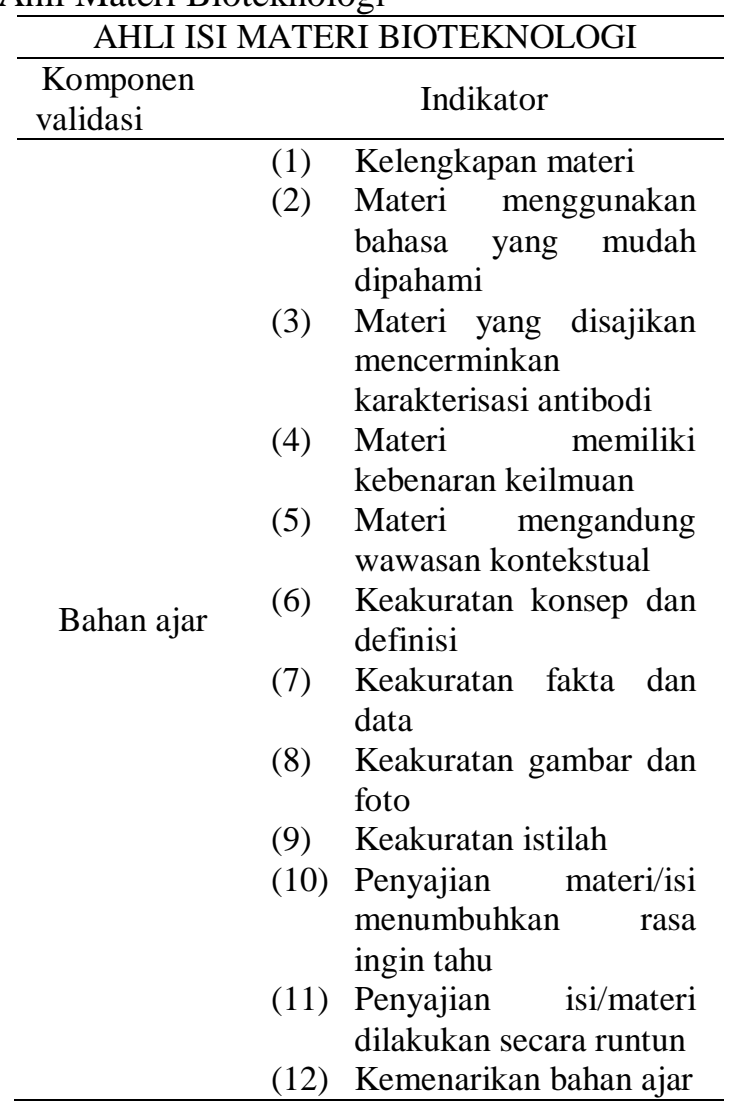

Tabel 3 Kisi-kisi Instrumen Lembar Validasi Ahli Media dan Desain Pembelajaran AHLI MEDIA DAN DESAIN PEMBELAJARAN

\begin{tabular}{ll} 
Komponen & \multicolumn{1}{c}{ Indikator } \\
validasi & \multicolumn{1}{c}{ (1) Format/ukuran buku } \\
& (2) Kualitas kertas \\
& (3) Kualitas cetakan \\
& (4) Kemenarikan desain \\
& cover \\
& (5) Tata letak isi buku \\
& konsisten \\
& (6) Tata letak isi buku \\
& harmonis \\
Bahan ajar & (7) Ketetapan lay out dan \\
& kualitas tipografi bahan \\
& ajar \\
& (8) Konsistensi penomoran \\
& dalam teks \\
& (9) Keakuratan ilustrasi \\
gambar, ilustrasi, dan \\
foto \\
(10) Perpaduan warna yang \\
serasi dan menarik \\
(11) Kejelasan bahasa \\
(12) Sederhana dan menarik \\
\hline
\end{tabular}

Tabel 4 Kriteria Penilaian Bahan Ajar

\begin{tabular}{cl}
\hline Skor & \multicolumn{1}{c}{ Indikator } \\
\hline 1 & Jika tidak baik/tidak sesuai \\
2 & Jika kurang baik/tidak sesuai \\
3 & Jika Baik/sesuai \\
4 & Jika sangat baik/sangat sesuai \\
\hline
\end{tabular}

\section{Implementation/Implementasi}

Kegiatan tahap keempat adalah implementasi (implementation). Pada tahap ini tidak dilakukan suatu implementasi karena hanya berupa uji coba kelompok sedang yang terdiri dari 12 mahasiswa yang telah menempuh matakuliah Bioteknologi.

\section{Evaluation/Evaluasi}

Tahap terakhir adalah melakukan evaluasi (evaluation). Evaluasi adalah proses untuk melihat apakah bahan ajar yang dikembangkan berhasil, sesuai dengan harapan awal atau tidak. Sebenarnya tahap evaluasi terjadi pada setiap empat tahap di atas. Evaluasi yang terjadi pada setiap empat tahap di atas itu dinamakan evaluasi formatif karena tujuannya untuk kebutuhan revisi (Supriatna dan Mulyadi, 2009). Revisi produk dilakukan terhadap draft pengembangan produk yaitu berupa bahan ajar Bioteknologi. Revisi didasarkan pada hasil validasi ahli materi. Dan ahli kegrafikan dengan mempertimbangkan saran-saran yang diberikan, setelah didapatkan hasil validasi selanjutnya dilakukan perbaikan dan penyempurnaan draft buku ajar tersebut sehingga dihasilkan produk akhir yang memenuhi kriteria.

\section{Analisis Data}

Terdapat dua teknik analisis data yang digunakan untuk mengolah data dari hasil tinjauan para ahli, yaitu menggunakan analisis deskriptif kualitatif dan deskripsi kuantitatif. 


\section{Analisis deskriptif kualitatif}

Analisis deskriptif kualitatif digunakan untuk mengolah data dari hasil review para ahli. Teknik analisis data ini digunakan dengan mengelompokkan informasi-informasi dari data hasil kualitatif yang berupa tanggapan dan saran perbaikan dari validasi ahli materi dan validasi ahli media dan desain pembelajaran. Analisis data dijadikan acuan untuk memperbaiki atau merevisi produk.

\section{Analisis deskriptif kuantitatif}

Untuk menganalisis skor yang terkumpul dari lembar validasi, maka digunakan statistik. Data dari lembar validasi dianalisis untuk mendapatkan gambaran tentang buku ajar yang dikembangkan. Setelah lembar validasi terkumpul, kemudian dihitung persentase dari tiap-tiap butir pertanyaan pada lembar validasi tersebut dengan persamaan yang digunakan yaitu:

$$
\begin{aligned}
& \mathrm{P} \\
& =\frac{\Sigma(\text { keseluruhan jawaban angket })}{\mathrm{N} x \text { bobot tertinggi } x \text { jumlah responden }} \times 100 \% \\
& \text { Keterangan: } \\
& \mathrm{P} \quad=\text { Persentase penilaian } \\
& \mathrm{N} \quad=\text { Jumlah item angket }
\end{aligned}
$$

Pemberian makna dan pengambilan keputusan tentang kualitas produk buku terdapat Tabel 5 tentang kriteria tingkat validitas yaitu.

Tabel 5 Pengambilan Keputusan Revisi Bahan

\begin{tabular}{ccc} 
Ajar & & \\
\hline Tingkat & Kualifikasi & Keterangan \\
Pencapaian & & \\
\hline $81-100$ & Sangat baik & Tidak perlu revisi \\
$61-80$ & Baik & Tidak perlu revisi \\
$41-60$ & Cukup baik & Direvisi \\
$21-40$ & Kurang baik & Direvisi \\
$0-20$ & Sangat kurang & Direvisi \\
& baik & \\
\hline
\end{tabular}

\section{HASIL DAN PEMBAHASAN Identitas produk}

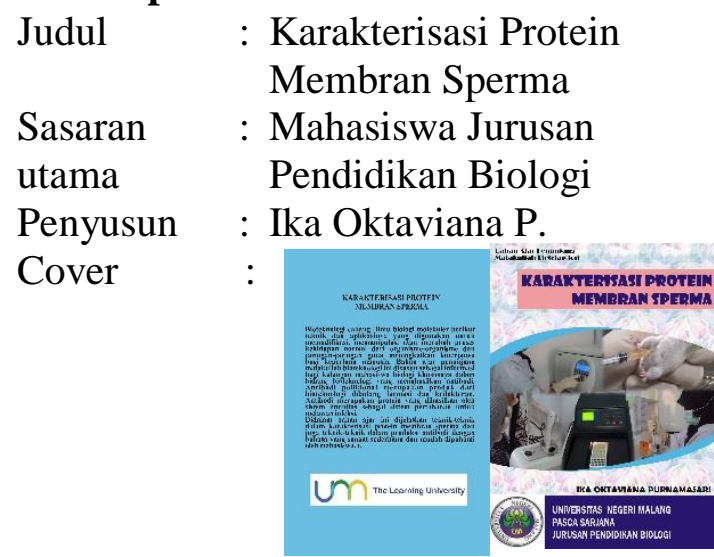

\section{Karakteristik}

Teks yang digunakan dalam bahan ajar ini adalah tipe Century dengan berbagai ukuran teks sesuai dengan kebutuhan pengguna. Ukuran kertas yang digunakan dalam bahan ajar ini adalah B5. Visual berupa gambar dalam bahan ajar ini dikumpulkan dari berbagai foto kegiatan penelitian dan dari jurnal dan buku teks sebagai penunjang.

\section{Tinjauan Kurikulum}

Pengembangan bahan ajar ini disusun berdasarkan tinjauan kurikulum yang ada pada matakuliah Bioteknologi pada Jurusan Biologi. Dengan hanya mengambil pada bidang kesehatan. Bahan ajar hanya menitik beratkan pada bahasan bioteknologi bidang yang menghasilkan produk berupa antibodi poliklonal.

\section{Tujuan Pembelajaran}

Tujuan pembelajaran yang diharapkan adalah 1) Mahasiswa mampu memahami prinsip dasar antibodi, 2) Mahasiswa mampu memahami karakterisasi protein membran sperma, 3) Mahasiswa mampu memahami teknik isolasi, teknik elektrofesis, teknik imunisasi, dan uji ELISA. 


\section{Isi Materi}

Materi yang terdapat didalam bahan ajar merupakan materi Aplikasi Bioteknologi bidang kesehatan yang meliputi pengertian dan prinsip bioteknologi, prinsip dan teknik analisis protein membran sperma yang merupakan hasil penelitian karakterisasi protein membran sperma di laboratorium.

Tabel 6. Revisi Bahan Ajar Oleh Dosen Ahli Bidang Studi

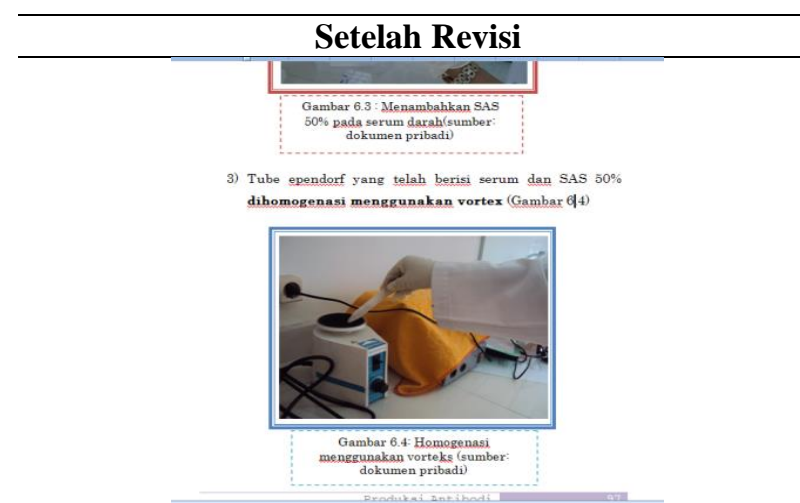

Penulisan yang benar :Di homogenasi menggunakan vorteks

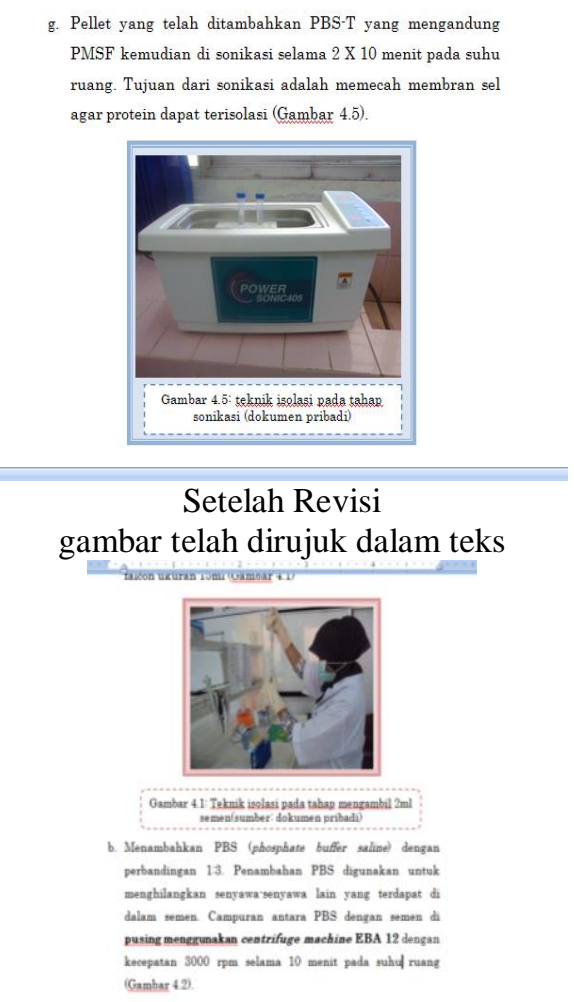

Penulisan yang benar : Di pusing menggunakan sentrifuge
Hasil perhitungan validasi oleh ahli bidang studi, ahli media pembelajaran presentase kemudian dicocokkan dengan kriteria penilaian pada Tabel 5 agar memperoleh makna dan dapat digunakan sebagai dasar pengambilan keputusan revisi media interaktif. Adapun ringkasan presentase total validasi dan keputusan media interaktif dapat dilihat pada Tabel 8.

Tabel 7. Revisi Bahan Ajar Oleh Dosen Ahli Media Dan Desain Pembelajaran

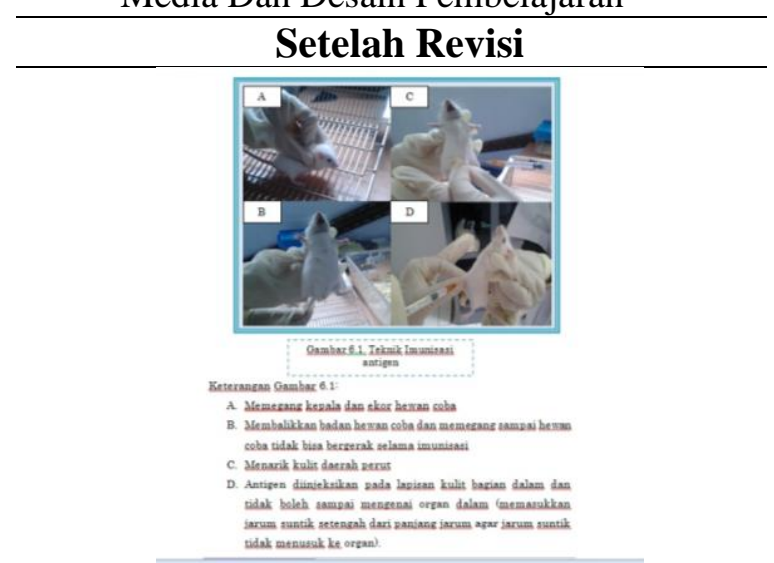

Gambar telah ditambahkan keterangannya e. Nenvambungkan kabel pada aliran listrik

f $\frac{\text { Nenvalakan komputer hingga muncul lavar seperti Gambar }}{49}$

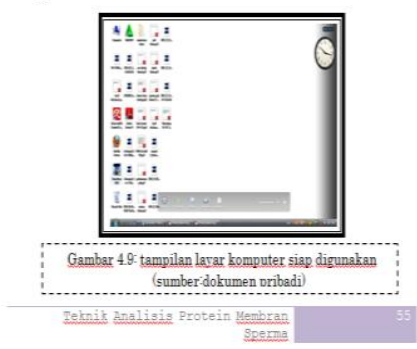

Tulisan keterangan gambar telah diperbesar Adapun langkah-langkah dalam isolasi protein adalah sebagai berikut.

a. Mengambil $2 \mathrm{ml}$ semen manusia dan diletakkan pada tabung falcon ukuran 15̆ml (Gambar 4.1)

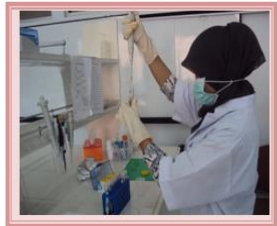

Gambar 4.1: teknik isolassi pada tahap mengambil $2 \mathrm{ml}$ semen sumber: dokumen pribadi

Teknik Analiaisa Protein Membran Sperna gambar telah dirujuk dalam teks 
Tabel 8. Ringkasan Penghitungan Persentase Total dan Keputusan Revisi Media Interaktif

\begin{tabular}{ccccc}
\hline No & Validator & Jumlah & $\begin{array}{c}\text { Persen } \\
\text {-tase }\end{array}$ & $\begin{array}{c}\text { Ketera- } \\
\text { ngan }\end{array}$ \\
\hline 1 & $\begin{array}{c}\text { Ahli materi } \\
\text { Bioteknologi } \\
\text { Ahli media } \\
\text { dan desain }\end{array}$ & 43 & $89,58 \%$ & $\begin{array}{c}\text { Sangat } \\
\text { baik }\end{array}$ \\
& $\begin{array}{c}\text { pembelajaran } \\
\text { Uji coba } \\
\text { kelompok } \\
\text { sedang }\end{array}$ & 299 & $83,75 \%$ & $\begin{array}{c}\text { Sangat } \\
\text { baik }\end{array}$ \\
\hline
\end{tabular}

Pengembangan bahan ajar berdasarkan hasil penelitian tentang karakterisasi antibodi protein membran sperma, mengharapkan mahasiswa mendapat pengetahuan baru tentang teknikteknik yang dilakukan dalam karakterisasi protein serta produksi antibodi poliklonal. Pengetahuan yang disampaikan kepada mahasiswa harus sesuai dengan indikator kompetensi yang telah dirumuskan sehingga tujuan dari pembelajaran tercapai. Adapun indikator yang harus mahasiswa capai antara lain 1) Mahasiswa mampu memahami prinsip dasar antibodi, 2) Mahasiswa mampu memahami teknikteknik produksi antibodi poliklonal, 3) Mahasiswa mampu memahami teknik isolasi, teknik elektrofesis, teknik imunisasi, dan uji ELISA. Dalam bahan ajar yang disusun telah memuat indikator kompetensi sehingga tujuan dari pembelajaran tercapai.

Bahan ajar memiliki peranan yang strategis dalam memfasilitasi kelancaran dalam proses pembelajaran (Sujarwo, 2008). Buku teks merupakan salah satu bahan ajar yang diperuntukkan bagi mahasiswa sebagai bekal pengetahuan dasar, dan digunakan sebagai sarana belajar dalam lingkup perkuliahan. Dipandang dari proses pembelajaran, penggunaan bahan ajar mempunyai peran penting. Jika tujuan pembelajarannya adalah untuk menjadikan mahasiswa memiliki berbagai kompetensi, maka perancangan bahan ajar harus memasukkan sejumlah prinsip yang dapat meningkatkan kompetensi yang hendak dimiliki mahasiswa.

Kusdiyanti (2011) mengungkapkan bahwa, buku yang disusun dalam kaitan dengan kurikulum hendaknya memperhatikan tujuan tertentu yang hendak dicapai melalui pendidikan yang dilakukan dengan menggunakan buku pelajaran yang bersangkutan. Oleh karena itu, sebelum buku pelajaran itu dikembangkan, penyusun atau penulis harus terlebih dahulu memahami tujuan satuan pendidikan, tujuan pendididkan dan cakupan materi semester, kelas atau satuan pendidikan tertentu.

Hasil pengembangan bahan ajar berupa buku teks penunjang matakuliah Bioteknologi, terdapat revisi yang dilakukan sesuai dengan prosedur penelitian pengembangan dengan mempertimbangkan saran dan masukan dari ahli isi materi, ahli media dan desain pembelajaran, serta dari uji perorangan dan kelompok sedang juga diperhatikan untuk penyempurnaan bahan ajar. Berdasarkan peraturan Menteri Pendidikan Nasional RI nomor 2 Tahun 2008 menjelaskan bahwa buku teks harus layak untuk dijadikan bahan ajar dan juga terdapat kriteria mutu (standart) buku teks pelajaran diantaranya, 1) kelayakan isi/materi, 2) kelayakan penyajian, 3) kelayakan bahasa, 4) kelayakan grafisan. Kriteria-kriteria tersebut telah tercantum dalam komponen lembar validasi yang dinilai oleh validator.

Hasil analisis data yang telah dilakukan terhadap pengembangan buku teks tentang karakterisasi protein membran sperma menjunjukkan hasil validasi buku teks layak untuk digunakan sebagai buku teks penunjang matakuliah Bioteknologi. Hasil kelayakan ini dilihat berdasarkan kebenaran materi yang disajikan pada buku teks penunjang matakuliah Bioteknologi dari ahli materi sebesar $89,58 \%$. Dengan adanya bahan ajar berbasis penelitian ini diharapkan dapat menghubungkan antara kajian teoritik dengan realitas yang ada. Hal 
yang demikian berdampak sangat baik bagi penguatan pemahaman mahasiswa terhadap yang konsep yang terkadang di dalam buku teks bersifat sangat abstrak ke tataran pemahaman yang lebih nyata

Validasi kelayakan buku teks juga dilakukan pada ahli media dan desain pengembangan, tujuan dari validasi ini adalah untuk menilai fisik buku, yang meliputi ukuran buku, jenis kertas, cetakan, ukuran huruf, warna, dan ilustrasi yang membuat pembaca menyenangi buku yang dikemas dengan baik dan akhirnya juga meminati untuk membacanya sehingga dapat digunakan oleh mahasiswa sebagai buku teks penunjang matakuliah Bioteknologi. Hasil validasi kelayakan dari ahli media dan desain pembelajaran sebesar $93,75 \%$, nilai tersebut menunjukkan kategori buku teks layak dengan keputusan uji tidak perlu revisi. Nilai kelayakan ini menunjukkan bahwa buku teks telah mencakup kriteria-kriteria yang harus dimiliki oleh buku teks.

Berdasarkan hasil uji coba kelompok sedang diperoleh data sebesar 88,98\%, yang menunjukkan kategori buku teks layak dengan keputusan uji tidak perlu revisi. Hal ini menunjukkan bahwa mahasiswa tertarik dalam membaca buku teks berbasis penelitian. Buku teks dengan sajian materi yang sederhana dapat memudahkan mahasiswa dalam memahami materi yang disampaikan dan bahasa yang komunikatif juga sangat diperlukan untuk menghubungkan pikiran dari penulis dengan pemahaman pembaca.

Buku teks yang dikembangkan merupakan hasil dari penelitian teknik produksi antibodi poliklonal protein membran sperma yang dituangkan menjadi suatu bahan pembelajaran bagi mahasiswa sehingga mahasiswa dapat memahami prinsip-prinsip dasar bioteknologi yang menghasilkan antibodi, sesuai dengan indikator yang akan dicapai pada rencana pembelajaran semester. Buku teks ini juga didukung oleh teori-teori yang relevan yang bertujuan untuk menjelaskan prinsip dari karakterisasi protein membran sperma. Selain itu, didalam buku teks ini juga menjelaskan tentang kendala-kendala yang diahadapi selama proses penelitian dengan tujuan mahasiswa memiliki sikap tidak mudah menyerah ketika mengalami kegagalan. Sehingga hasil penelitian yang dilakukan dapat memberi manfaat pada mahasiswa

Hal ini sesuai dengan pernyataan Ardhana (2002) bahwa penelitian pengembangan dilakukan untuk menjembatani antara penelitian dan praktik pendidikan. Pengembangan kurikulum dan proses belajar mengajar berbasis riset (research enhached teacing/learning, RETL), dalam berbagai model, telah berkembang dengan sangat baik dan diyakini merupakan pilihan yang tepat untuk pola kegiatan belajar mengajar masa kini. Brew (2007) dan Healey (2005) secara senada memberikan gambaran manfaat yang sangat baik dari pentingnya strategi menumbuhkan jalinan (link) yang kuat antara riset dan pengajaran di jenjang pendidikan tinggi.

Hasil bahan ajar yang telah dikembangkan tentunya memiliki kelebihan dan kelemahan. Kelebihan bahan ajar yang telah dikembangkan yaitu, 1) bahan ajar disusun dari hasil penelitian secara sistematis sehingga pembaca mendapatkan gambaran langsung tahapantahapan dalam penelitian, 2) bahan ajar dilengkapai dengan tujuan pembelajaran sehingga dapat memandu mahasiswa dalam melakukan kegiatan pembelajaran, 3) materi yang disajikan menggunakan bahasa yang sederhana dan mudah dipahami oleh mahasiswa, 4) bahan ajar disusun secara sistematis mulai dari materi, tahap-tahap dalam penelitian serta paparan data hasil penelitian sehingga memudahkan mahasiswa dalam mempelajari buku teks tersebut, 5) bahan ajar bisa dibaca dimana saja dan juga dapat dipahami tanpa penjelasan dari dosen. Kelemahan dalam 
bahan ajar yang telah disusun berisi satu kompetensi dasar saja karena digunakan sebagai bahan ajar penunjang matakuliah bioteknologi dan juga buku teks ini belum dilakukan uji coba klasikal karena keterbatasan waktu.

\section{SIMPULAN}

Hasil dan analisa data yang telah dilakukan terhadap pengembangan bahan ajar tentang karakterisasi protein membran pada mata kuliah bioteknologi diketahui bahwa berdasarkan hasil validasi bahan ajar layak untuk digunakan sebagai media pembelajaran. Kelayakan ini dilihat dari segi kebenaran materi oleh ahli materi yaitu sebesar 89,58\%, kelayakan bahan ajar sebagai media pembelajaran oleh ahli media pembelajaran sebesar $93,75 \%$ dan berdasarkan hasil uji coba kelompok sedang diperoleh data sebesar 88,98\%, yang menunjukkan kategori buku teks layak dengan keputusan uji tidak perlu revisi.

\section{UCAPAN TERIMA KASIH}

Penelitian ini tidak akan terselesaikan tanpa bantuan dari Prof. Sutiman Bambang Sumitro, M.Sc, D.Sc dan Dr. Umie Lestari, M.Si , M.Si selaku pembimbing. Dr. Endang Suarsini, M.Ked dan Dr. Aje Toenlioe, M.Pd selaku validator. Serta teman-teman seangkatan 2014 yang banyak membantu terlaksananya Penelitian ini.

\section{DAFTAR PUSTAKA}

Ardhana, I W. (2002). Konsep Penelitian Pengembangan dalam Bidang Pendidikan dan Pembelajaran. Makalah disampaikan pada Lokakarya Nasional Angkatan II Metodologi Penelitian
Pengembangan Bidang Pendidikan dan Pembelajaran, Malang, 22-24 Maret.

Brew, A. (2007). Imperatives and challenges in integrating research and teaching: A case study. Carrick Institute for Learning and Teaching in Higher Education Discipline-Based Development Forum: Teaching/Research Nexus. Adelaide, 29-30 August 2007

Binadja, Achmad. (2005). Pemikiran dalam SETS (Science, Environment, Techmologi, and Society). Semarang:Program Pasca Sarjana Unesa

Branch, Robert Maribe. (2009). Instructional Design: The ADDIE Approach. Springer New York Dordrecht Heidelberg London

Depdiknas. (2008).

Panduan Pengembangan Bahan Ajar. Dokumen Pendidikan Nasional.

Jenkin, A. and Healey, M. 2005. Istitutional Strategis To Link Teaching And Research. The Higher Education Academy. Oktober 2005

Kusdiyanti, Heny. (2011). Pelatihan Pengembangan Bahan Ajar Kearsipan Berbasis Potensi Lokal dalam rangka Program pemberdayaan Siswa Binaan Labsosdik di SMK se-Malang. UM: LP3.

Primrose, S.B. (2003). Modern Biotechnology. Oxford: Blackwell Scientific Publications.

Roitt. Nahta. (2012). Perkembangan Bioteknologi Farmasi (Online) (http://www.hindawi.com/isrn/on cology/2012/428062/) diakses tanggal 22 Desember 2013. 